\title{
AN EMPIRICAL INVESTIGATION OF THE IMPORTANCE OF COST-PLUS PRICING
}

\author{
Chris Guilding \\ School of Accounting and Finance, \\ Griffith University \\ Southport, Queensland, \\ AUSTRALIA \\ Colin Drury \\ Huddersfield University Business School \\ Huddersfield \\ West Yorkshire \\ ENGLAND \\ Mike Tayles \\ Bradford Management Centre \\ University of Bradford \\ Bradford \\ West Yorkshire \\ ENGLAND
}




\title{
AN EMPIRICAL INVESTIGATION OF THE IMPORTANCE OF COST-PLUS PRICING
}

\begin{abstract}
The results of a survey appraising the degree of importance attached to cost-plus pricing in large Australian and United Kingdom companies are reported. A relatively high degree of importance attached to cost-plus pricing is noted, although there appears to be a substantial number of companies that use cost-plus pricing for a relatively small sub-set of products and services. Two factors have been found to play statistically significant roles in connection with importance attached to cost-plus pricing. Companies confronted by high competition intensity attach relatively high degrees of importance to cost-plus pricing and manufacturing companies attach a relatively low degree of importance to cost-plus pricing.
\end{abstract}

Key words: Cost-plus pricing, costing, competition intensity, manufacturing. 


\section{AN EMPIRICAL INVESTIGATION OF THE IMPORTANCE OF COST-PLUS PRICING}

\section{Introduction}

It is widely-noted in the normative literature that cost information can play a key role in determining selling prices (Drury, 2000; Horngren et al, 2000; Langfield-Smith et al, 1998). This would appear to be particularly the case for organizations that have some discretion in setting their selling prices or where a product or service is highly customized or a market leader. By way of contrast, for many firms prices are viewed as a function of market forces and there is minimal scope for discretion in price-setting. Also, small firms operating in an industry where prices are set by the dominant market leaders will have little influence over the prices of products or services. In these price-taking firms the scope for cost-plus pricing is likely to be limited. In such firms it is to be expected that cost information is viewed primarily as a key factor to be considered when attempting to optimise the output and mix of products and services in light of extant market prices.

A literature search designed to uncover cost-plus pricing studies and covering periodical publications spanning the last two decades has revealed only two empirical studies with a specific focus on cost-plus pricing. These studies reported that cost-plus pricing, often using full costs, is widely-used. Mills (1988) in surveying 52 UK manufacturing and 42 service companies reported cost based methods reliant on full/absorption costing principles were the primary basis for determining prices under normal conditions. In the USA, Govindarajan and Anthony (1983) reported 74\% of companies used some form of "full cost" as a basis for the mark-up when setting selling prices. Subsequent to the 1980's, the use of costs in pricing has commanded little more than cursory research attention as a part of surveys concerned with a breadth of costing and management accounting practices. For example, in Australia, Joye and Blayney (1990) reported pricing 
as the most important reason for allocating overhead costs and that product cost was an important determinant of price (ranking ahead of competitor and consumer factors). In the UK, Bright et.al. (1993) reported that 90\% of their survey respondents employed costing techniques and practices for product pricing.

The minimal empirical interest shown in cost-plus pricing is particularly surprising given the recent explosion of research interest in product costing that has occurred. Surveys of product costing and activity-based costing ( $\mathrm{ABC}$ ) practice have been undertaken in the UK (Drury et al, 1993; Drury and Tayles, 2000; Innes and Mitchell, 1991; 1995; Innes et al., 2000), USA (Emore and Ness, 1991; Green and Amenkhienan, 1992), Australia (Joye and Blayney, 1990; Dean et al., 1991), Canada (Armitage and Nicholson, 1993), India (Joshi 1998), Finland (Lukka and Granlund, 1996), Sweden (Ask and Ax, 1992), New Zealand (Lamminmaki and Drury, 2001) and Norway (Bjonenak, 1997a; 1997b). ${ }^{1}$

This product costing research had tended to focus on deriving empirical data relating to the use of different costing methods (typically variable or absorption costing), the accuracy of product costs, and the influence of financial accounting requirements on cost determination for decision-making as well as issues relating to $\mathrm{ABC}$. The $\mathrm{ABC}$ research has tended to focus on usage levels, business applications, implementation problems and the identification of factors influencing success and failure of ABC. This interest in product costing research appears to have been triggered by two main factors. First, the environment in which product costing is undertaken has undergone substantial change. This includes changes in information technology, cost structures and the manufacturing and competitive environment. These changes have generated increased product costing interest amongst both academics and practitioners. Second, debate concerning product 
costing was initiated by several notable criticisms of traditional product costing systems (e.g., Cooper, 1990, Johnson and Kaplan, 1987; Kaplan, 1984, 1990) and the emergence of ABC systems.

Somewhat typifying much of the recent research into management and costing practices, Chenhall and Langfield-Smith (1998) appraised the adoption and benefits of management accounting practices in Australian companies. They did not, however, examine pricing within the traditional and contemporary management accounting techniques they investigated, despite the fact that the scope of their enquiry included absorption costing, cost-volumeprofitability analysis, ABC, target costing and product life cycle analysis. It is notable that in their review of research into product costing practice, Brierley et. al. (2001) make reference to pricing and conclude:

“... there is a need to expand prior research to include an understanding of the relative importance of product costs for determining prices, and the circumstances under which product costs may be a less suitable basis for determining selling prices....” (p. 232).

In light of the findings of our literature search and also Brierley's (2001) observation, it appears that further work concerned with the application of cost-plus pricing is warranted. Furthermore, little has been done to investigate the contingent factors affecting the application of cost-plus pricing. In order to address the relative paucity of recent research concerned with cost-plus pricing, this study had two specific objectives:

a) to appraise the relative importance of cost-plus pricing,

b) to develop and test hypotheses concerned with contingent factors that might affect

\footnotetext{
${ }^{1}$ For a review of the management accounting picture in Europe see Bhimani (1996) or Brierley's (2001) overview of the findings concerned with product costing.
} 
the degree of importance attached to cost-plus pricing.

The remainder of the paper is organised in the following manner. In the context of a review of the most pertinent literature, the next section develops a theoretical framework concerned with factors that might affect the adoption of cost-plus pricing. Subsequent sections address, in turn, the research design, the survey's findings and a conclusion that discusses the study's findings as well as its limitations.

\section{Towards a contingency theory of cost-plus pricing}

Hypotheses concerning three contingent factors that might affect the importance attached to cost-plus pricing are developed in this section. These three factors are competition intensity, company size and industry.

\subsection{Competition intensity}

Competition intensity is a construct that would appear to have the potential for profound implications with respect to pricing practice. Kohli and Jaworski (1990) claim that increased competition requires companies to adopt a heightened customer focus. A heightened customer focus can be expected to result in increased deliberations concerning prices charged to customers. One would expect that a key input to such deliberations is cost information.

High competition can be expected to result in lower margins due to the pressure to match or under-cut prices charged by competing firms. Competitive pricing can be expected to 
put cost information at a premium. In a highly competitive market, accurate cost information would appear to be a particularly important resource for marketing and sales personnel concerned with how low they can price a product and still cover variable costs (if a short-term “variable costing” philosophy is adopted) or fixed and variable costs (if a long-term "full-costing” philosophy is adopted). Further, in the context of intense competition, companies can be expected to attempt to differentiate their products and services by customising them to the specific needs of customers. Such customisation can be expected to increase the importance of cost-plus pricing, as increased product and service customisation will result in increased price customisation.

This view on the importance of cost information in a competitive market provides an extension of several earlier studies concerned with management accounting systems and competition intensity (Govindarajan, 1984; Guilding and McManus, 2002; Khandwalla, 1972; Libby and Waterhouse, 1995; Merchant, 1981; 1984; Simons, 1990). A theme in the findings of these studies is the view that competition intensity is positively related to more extensive use of management accounting system information. This theme appears consistent with an expected positive relationship between competition intensity and importance attached to cost-plus pricing.

Proposition 1: Competition intensity is positively related to importance attached to costplus pricing.

\subsection{Company size}

It is expected that company size is positively related to importance attached to cost-plus pricing. A fundamental issue in price-setting practice concerns the extent to which a 
company is a price-maker or a price-taker. Price-takers will have less reason to draw on cost information when pricing their products or services, as prices are determined by the market. Large companies can be expected to be major players in markets and therefore have a greater capacity to influence prices charged. In light of larger companies' greater propensity to act as price-makers, it is expected they will have greater cause to draw on cost information when pricing goods and services.

Previous contingency studies have noted a positive relationship between company size and management accounting system sophistication (Bruns and Waterhouse, 1975; Gordon and Miller, 1976; Guilding, 1999; Merchant, 1981). In light of economies of scale that can be reaped in larger companies, it seems reasonable to expect larger companies to have more developed accounting systems that provide sufficient flexibility to support cost-plus pricing.

Proposition 2: Company size is positively related to importance attached to cost-plus pricing.

\subsection{Industry}

The third proposition concerns an expected cross-industry effect with respect to cost-plus pricing. Relative to the service and retail sectors, companies in the manufacturing industry have relatively high overheads due to investment in plant and machinery infrastructure. They also have a greater proportion of joint product costs. These issues inhibit the accuracy of full costing at the individual product level. As a result cost information at the level of the product to be priced would appear to be relatively incomplete in the manufacturing sector. 
In comparison to the manufacturing sector, it is relatively easy for companies in the retail sector to track their main costs to the items that are to be retailed. This is because the retailer will have purchase records pertaining to all items that are to be retailed. The relatively high proportion of direct costs in the retail sector is expected to result in the sector attaching a relatively high degree of importance to cost-plus pricing.

Many companies in the service sector have a relatively high labour content with respect to services provided. In addition, this labour component tends to be relatively traceable. Unlike much of the manufacturing and retail sectors, many items sold in the service sector have no exact substitutes (e.g., a menu item in a restaurant at hotel A is unlikely to represent the same eating experience as the same menu item at a restaurant in hotel B). Due to the service industry's greater ability to differentiate services offered, it is expected to be more orientated towards price making than price taking. This relatively high "pricemaking” orientation of the service sector combined with its relatively high content of traceable labour cost in the units to be priced are expected to result in the service sector attaching relatively high importance to cost-plus pricing.

Consistent with the rationale developed above, it is expected that, compared to the retail and service industries, the manufacturing industry will attach a relatively low importance to cost-plus pricing.

Proposition 3: Companies in the manufacturing industry attach relatively low importance to cost in price setting.

\section{Research method and variable measurement}




\subsection{Sampling procedures}

Data was collected via a mailed survey of Australian and United Kingdom companies. This strategy was adopted to enhance the robustness and international generalisability of the study's findings. The survey questionnaire together with a covering letter and pre-paid return envelope was mailed to the chief accountant in each company sampled.

In Australia, the initial sample comprised the largest 300 companies (measured by market capitalisation), identified in the "Shareholder" CD-Rom database. No Australian address could be found for 13 of these companies, and 7 companies indicated in writing that the issues raised in the survey were not applicable to them. ${ }^{2}$ This yielded a final adjusted sample size of 280 companies. Two mailings of the questionnaire provided 90 responses, i.e., a response rate of $31 \%$.

In the UK, a sample of 631 companies was drawn up by identifying profit-making companies that employed two or more members of the Chartered Institute of Management Accountants with more than five years post-qualification experience. This approach was taken in an attempt to focus on companies where a relatively well-developed management accounting system might be expected. Replies were received from 187 of the sampled accountants, i.e., a response rate of $30 \%$.

A test for non-response bias has been conducted by comparing the responses provided by “first-mailing” respondents with those provided by "second-mailing” respondents. A

\footnotetext{
2 These companies tended to be associated with the mining industry. They indicated that as they had no customers (e.g., they were at an "exploration stage") they were not pricing any products.
} 
statistical comparison of these two data sets has revealed no statistically significant differences. In addition, as part of an attempt to increase the response rate and ascertain reasons for non-response, 23 of the non-respondents in Australia were contacted by telephone. The most widely-cited reasons for not responding were "not enough time” and “completion of surveys contravened company policy”. No factors cited for non-response suggest a non-response bias threat. A summary of the response pattern in the two countries is provided in Table 1. Table 2 provides an industrial classification of the respondents' companies.

\section{INSERT TABLES 1 \& 2 ABOUT HERE}

\subsection{Measurement of variables used in hypothesis testing}

\subsubsection{Importance of cost-plus pricing}

Two items designed to measure importance attached to cost-plus pricing were included in the questionnaire. For the first item, respondents were asked to indicate the relative importance of a cost-plus selling price when determining final selling price on a seven point Likert scale ranging from " 1 ” (of little importance) to “7” (of vital importance). For the second item, respondents were asked to indicate the proportion of their organisation's external sales that use a cost-plus approach in price setting. Responses were recorded on a 1-7 ordinal scale that corresponded to seven percentile ranges. ${ }^{3}$ As the scores on these two

\footnotetext{
3 “1” corresponded to $0 \%-10 \%$, “2” corresponded to 11\%-20\%, “3” corresponded to $21 \%-30 \%$, “4” corresponded to $31 \%-40 \%$, “5” corresponded to $41 \%-50 \%$, “6” corresponded to $51 \%-70 \%$, and “7” corresponded to “Over $70 \%$. 
measures were highly correlated at the .01 level of significance, the importance of costplus pricing has been measured by aggregating the scores of the two items.

\subsubsection{Competition intensity}

Two items measuring competition intensity have been used. The first item asked respondents to indicate the extent of competition for their organisation's major products/services on a Likert scale ranging from “1” (low) to “7” (extremely intensive). The second item asked respondents to indicate the extent of price competition in their industry on a Likert scale ranging from "1" (of negligible intensity) to "7” (extremely intensive). As the scores on these two measures were positively correlated at the .01 level of significance, competition intensity has been measured by aggregating the scores for the two items.

\subsubsection{Company size}

Annual sales turnover has been used to measure company size. Seven sales ranges were provided in the questionnaire and respondents were asked to indicate in which range their current annual level of sales lies. The seven sales ranges were ordinally numbered on a 1-7 scale and the ordinal score has been used as the measure of size. ${ }^{4}$

\subsubsection{Industry}

Respondents were asked to indicate which of six industrial sectors represents the main

\footnotetext{
4 In the UK questionnaire these seven turnover ranges were: $0-£ 65 \mathrm{~m}, £ 66 \mathrm{~m}-£ 125 \mathrm{~m}, £ 126 \mathrm{~m}-£ 185 \mathrm{~m}, £ 186 \mathrm{~m}$ $£ 250 \mathrm{~m}, £ 251 \mathrm{~m}-£ 500 \mathrm{~m}, £ 501 \mathrm{~m}-£ 750 \mathrm{~m}$, over $£ 750 \mathrm{~m}$. As the Australian $\$ /$ UK $£$ exchange rate at the time of the survey approximated to 2.5, the seven turnover ranges in the Australian questionnaire were generated by
} 
business of their company. The six sectors were: manufacturing, retail, service, financial and commercial, conglomerate, and other. ${ }^{5}$

\section{Results}

\subsection{The relative importance of cost-plus pricing}

The study's first objective concerns an appraisal of the relative importance of cost-plus pricing. Descriptive statistics pertaining to the two measures of the importance of costplus pricing are presented in Tables 3 and 4. To provide further insight into the incidence of cost-plus pricing, this data has been classified by industry. The statistics summarised in Table 3 were collected via the single questionnaire item that asked respondents to record the importance of the derived cost-plus selling price in determining the final selling price on a seven point Likert scale ranging from " 1 " (of little importance) to "7” (of vital importance). Data in Table 4 pertain to the questionnaire item that asked respondents to indicate the proportion of their organisation's external sales that use a cost-plus approach in price setting.

\section{INSERT TABLES 3 \& 4 ABOUT HERE}

The industry sectors in Tables 3 and 4 are presented in descending order of importance

multiplying the UK turnover ranges by a factor of 2.5 .

5 Only 3 respondents (i.e., $1 \%$ of all respondents) identified their company as in the "conglomerate" sector. As a result, this sector has been collapsed with the "other" sector. These combined sectors are referred to as "miscellaneous" in all data analyses provided in the paper. For the purposes of the regression analysis described in the next section, the financial sector has been treated as aligned to the service sector and no specific 
attached to cost-plus pricing. In Table 3 the means range from 5.00 for the financial and service sectors to 3.35 for the "miscellaneous" category. In Table 4 the means range from 5.36 for the retail sector to 2.72 for the "miscellaneous" category. When the two tables are considered together, a discernible pattern is evident. In both tables the manufacturing and miscellaneous sectors rank the lowest. This distinction between these two sectors and the other three industrial categories is particularly evident in Table 3 where a gulf appears between the mean usage rates of cost-plus pricing in the financial, retail and service sectors relative to the manufacturing and miscellaneous sectors.

Overall, the data collected suggest that cost information plays a relatively important role in price setting. It is pertinent to note that with respect to Table 3, for four of the five industry groups analysed, the mean score measure of the importance of cost-plus pricing is above the mid-point of the "of little importance - of vital importance" measurement scale. In addition, $65 \%$ of the respondents selected a score that was at or above the mid-point of the measurement scale. A more polarised picture emerges in connection with Table 4, however. Respondents tended to see cost-plus pricing being used for either a large or small proportion of their sales. Taken together, the two tables suggest that while respondents regard cost-plus pricing as important, there is a large cross-company variation in the proportion of each companies' sales that use cost-plus pricing. It appears that a fairly large proportion of companies use cost-plus pricing for a small sub-set of their total sales. Relative to the other industrial sectors, the retail sector uses cost-plus pricing for a significantly greater proportion of its sales (chi-square $p<0.01$ ).

With respect to the miscellaneous industrial category, it is apparent from Table 2 that most of the sample companies representing this sector are Australian (48\% of the Australian 
respondents identified their companies with this industrial category). A distinguishing feature of the Australian economy relative to other economies in the Western world is its high degree of primary industry commerce (i.e., mining, forestry, agriculture, fishing, etc.). Due to the limited ability of primary producers to differentiate their products, it appears reasonable to anticipate that primary industry companies will tend to be pricetakers rather than price-makers. This factor may well lie behind the low importance attached to cost-plus pricing by the miscellaneous industrial category. ${ }^{6}$

\subsection{Hypothesis testing}

Regression analysis was used to test the three hypotheses by fitting the data for cost-plus pricing to the following equation which includes country as a control variable:

$$
Y=b_{1}+b_{2} C O M P+b_{3} S I Z E+b_{4} M A N U F+b_{5} C O U N T R Y+e
$$

where:

Y $\quad$ importance of cost-plus pricing;

COMP = competition intensity;

SIZE $\quad=$ sales turnover measure;

MANUF = manufacturing industry; dummy variable set equal to one (1) if company is in the a manufacturing industry, otherwise zero (0);

COUNTRY = dummy variable set equal to one (1) if company is based in the UK and zero (0) if the company is based in Australia;

\footnotetext{
${ }^{6}$ With the benefit of hindsight, this rationale suggests that "primary industry" should have been included as an industrial category in the "industry" measure. Further research concerned with cost-plus pricing in Australia or any country with a significant primary industry sector would benefit from considering this issue when designing data
} 
The results of the regression are summarised in Table 5. This table presents support for proposition 1 that posited a positive relationship between competition intensity and importance attached to cost-plus pricing, as the coefficient for competition intensity is positive and statistically significant $(p<0.10)$. Support is also provided for proposition 3 that posited a negative relationship between companies in the manufacturing industry and importance attached to cost-plus pricing, as the coefficient for manufacturing was negative and statistically significant $(p<0.10)$. No support is provided, however, for proposition 2 which concerned a positive relationship between company size and importance attached to cost-plus pricing.

\section{Summary and conclusions}

It was noted in the introductory section that despite an increase in surveys of management accounting practice generally, limited attention has been given to cost-plus pricing. This study represents an attempt to contribute to our understanding of cost-plus pricing in two ways. Firstly it has appraised the degree to which companies attach importance to cost-plus pricing and, secondly it has investigated for contingent relations between organisational factors and the relative importance attached to cost-plus pricing.

With respect to the first aspect of the study, it appears that in large companies in Australia and the United Kingdom cost data represents a relatively important information source that is widely-drawn upon in price setting. When asked to indicate the relative importance of the cost-plus approach in determining the final selling price, most of the survey 
respondents recorded a score at or above the mid-point of the "of little importance" - "of vital importance” measurement scale. A relatively polarised picture emerges, however, with respect to the proportion of each companies' sales that use cost-plus price setting. While cost-plus pricing appears to be widely perceived as important, it appears there is a substantial number of companies that use cost-plus pricing only for a small subset of their product and service lines.

With respect to the contingency aspect of the study, it has been found that competition intensity and industrial sector play significant roles with respect to the degree of importance attached to cost-plus pricing. The finding that competition intensity is positively related to the importance of cost-plus pricing can be seen to extend prior work concerned with competition intensity and accounting system design (eg., Bromwich, 1990; Khandwalla, 1972; Merchant, 1981; Simons, 1990). The significant role played by competition intensity in the connection with accounting system design and use of accounting data appears to be one of the more enduring relationships uncovered by management accounting research. Further work in this area may well benefit from using a less subjective indicator of competition intensity such as the Herfindahl-Hirschmann index ( $H$ index). This index has been widely-used in economics research (Coate and McChesney, 1992; Farrell and Shapiro, 1990; Werden, 1991). Tymon et al (1998) have drawn attention to the degree to which competition intensity is associated with environmental uncertainty. This is a construct that has been invoked in several prior accounting studies (Chenhall and Morris, 1986; 1993; Govindarajan, 1984; Gul and Chia, 1994), and it may represent a useful contingency factor in any further work concerned with the degree of importance attached to cost-plus pricing.

The finding that the manufacturing sector attaches relatively low importance to cost-plus 
pricing, highlights the importance of carefully selecting industrial sectors in any case study research concerned with the way in which cost-plus price setting is conducted. A potentially fruitful research endeavour might involve identifying a manufacturing company that attaches high importance to cost-plus pricing. Through case study work an attempt could be made to determine the factors that lie behind the subject company taking an atypical approach to pricing.

A somewhat perplexing aspect of this study concerns the failure to find a statistically significant positive relationship between company size and cost-plus pricing. The view that larger firms will enjoy more market dominance and therefore have a relative "pricemaking” orientation offers considerable intuitive appeal. A factor that may partially account for this study's failure to uncover a relationship between company size and costplus pricing is the fact that many large firms can be expected to offer a relatively large range of products and services. A significant proportion of these products and services may have a limited market share. As a result, in absolute terms, large firms may have a greater number of products and services with a small market share. In light of this, in any further research that builds on this study, it would be advisable to focus on the relationship between a particular product's market share and the use of cost-plus pricing. It is to be expected that a high market share is positively related to a propensity to use cost-plus pricing.

The study's findings should be interpreted in the context of generally acknowledged limitations associated with survey research. Because of these limitations and in light of limited prior research into cost-plus pricing, further research of the issues addressed is to be encouraged. The degree of importance attached to cost-plus pricing suggests there is considerable scope for further studies designed to improve our understanding of the nature 
and different forms that cost-plus pricing may assume in a range of organisational settings. The contingency design of this study has abstracted variables at the corporate level, i.e., competition intensity, size and industry were all considered at the total company level. As Table 4 highlights a high incidence of companies using cost-plus pricing for some, but not all, products and services sold, further insights may be achieved by conducting a contingency analysis that appraises the impact of product and service attributes on importance attached to cost-plus pricing. 
TABLE 1

SUMMARY OF SURVEY REPLIES

\begin{tabular}{|c|c|c|c|c|c|}
\hline & $\begin{array}{c}\text { Questionnaires } \\
\text { mailed }\end{array}$ & $\begin{array}{l}\text { First mailing } \\
\text { responses }\end{array}$ & $\begin{array}{l}\text { Second mailing } \\
\text { responses }\end{array}$ & $\begin{array}{c}\text { Total } \\
\text { responses }\end{array}$ & $\begin{array}{l}\text { Unadjusted } \\
\text { response rate }\end{array}$ \\
\hline Australia & $\frac{287}{287}$ & 62 & 28 & 90 & $31 \%$ \\
\hline United Kingdom & 631 & 135 & 52 & 187 & $30 \%$ \\
\hline
\end{tabular}

TABLE 2

INDUSTRIAL CLASSIFICATION OF RESPONDENTS

\begin{tabular}{|c|c|c|c|c|c|c|}
\hline & \multicolumn{2}{|c|}{ Australia } & \multicolumn{2}{|c|}{ United Kingdom } & \multicolumn{2}{|c|}{ Total } \\
\hline & $\underline{n}^{\bar{a}}$ & $\underline{\%}$ & $\underline{n}^{\mathrm{b}}$ & $\underline{\%}$ & $\underline{n}$ & $\underline{\%}$ \\
\hline Manufacturing & 19 & 23 & 128 & 69 & 147 & 55 \\
\hline Retail & 6 & 7 & 9 & 5 & 15 & 6 \\
\hline Service & 12 & 15 & 26 & 14 & 38 & 14 \\
\hline Financial \& Commercial & 6 & 7 & 15 & 8 & 21 & 8 \\
\hline Miscellaneous & $\underline{39}$ & 48 & 7 & 4 & 46 & 17 \\
\hline & $\overline{82}$ & $\overline{100}$ & $\overline{185}$ & $\overline{\underline{100}}$ & $\overline{267}$ & $\overline{100}$ \\
\hline
\end{tabular}

a: 8 of the Australian respondents failed to indicate their company’s industrial sector.

b: 2 of the UK respondents failed to indicate their company's industrial sector.

TABLE 3

Cross-industry analysis of the importance of cost-plus analysis in determining the final selling price

\begin{tabular}{|c|c|c|c|c|c|c|c|c|c|}
\hline \multicolumn{10}{|c|}{ \% Frequency distribution } \\
\hline Industry & Mean & $\begin{array}{c}\text { St. } \\
\text { Dev'n }\end{array}$ & $\underline{\underline{1}}(\underline{\mathrm{low}})$ & $\underline{2}$ & $\underline{3}$ & $\underline{4}$ & $\underline{5}$ & $\underline{6}$ & $\stackrel{7}{\text { (high) }}$ \\
\hline Financial & 5.00 & 1.69 & 0 & 12.5 & 12.5 & 0 & 25 & 37.5 & 12.5 \\
\hline Service & 5.00 & 1.95 & 8.7 & 4.3 & 8.7 & 13.0 & 17.4 & 17.4 & 30.4 \\
\hline Retail & 4.91 & 1.14 & 0 & 0 & 9.1 & 27.3 & 36.4 & 18.2 & 9.1 \\
\hline Manufacturing & 4.16 & 1.72 & 7.4 & 13.7 & 15.8 & 13.7 & 24.2 & 18.9 & 6.3 \\
\hline Miscellaneous & 3.35 & 2.06 & 26.1 & 17.4 & 13 & 8.7 & 17.4 & 8.7 & 8.7 \\
\hline
\end{tabular}


TABLE 4

Cross-industry analysis of the proportion of sales that use a cost-plus approach in price setting

\begin{tabular}{|c|c|c|c|c|c|c|c|c|c|}
\hline & & & \multicolumn{7}{|c|}{ \% Frequency distribution } \\
\hline Industry & Mean & $\begin{array}{c}\text { St. } \\
\text { Dev'n }\end{array}$ & $(\underline{1})$ & $\underline{2}$ & $\underline{3}$ & $\underline{4}$ & $\underline{5}$ & $\underline{6}$ & $\stackrel{7}{\text { (high) }}$ \\
\hline Retail & 5.36 & 2.62 & 18.2 & 9.1 & 0 & 0 & 0 & 9.1 & 63.6 \\
\hline Financial & 5.00 & 2.83 & 28.6 & 0 & 0 & 0 & 14.3 & 0 & 57.1 \\
\hline Service & 4.04 & 2.40 & 17.4 & 21.8 & 13.0 & 0 & 8.7 & 13.0 & 26.1 \\
\hline Manufacturing & 3.65 & 2.40 & 26.2 & 21.1 & 8.4 & 5.3 & 5.3 & 11.6 & 22.1 \\
\hline Miscellaneous & 2.74 & 2.49 & 60.9 & 4.3 & 4.3 & 0 & 8.7 & 4.3 & 17.4 \\
\hline
\end{tabular}

TABLE 5

Cost-plus price setting regression analysis

\begin{tabular}{|c|c|c|c|c|c|}
\hline Variable & Coefficient & Value & $\underline{\text { Std. Error }}$ & $\underline{t}$ & $\underline{p}$ \\
\hline Intercept & $b_{1}$ & 4.968 & 1.509 & 3.292 & $<0.01$ \\
\hline Competition & $b_{2}$ & 0.155 & 0.132 & 1.845 & $<0.1$ \\
\hline Size & $b_{3}$ & 0.046 & 0.147 & 0.558 & n.s. \\
\hline Manufacturing & $b_{4}$ & -0.147 & 0.679 & -1.710 & $<0.1$ \\
\hline Country & $b_{5}$ & 0.135 & 0.722 & 1.553 & n.s. \\
\hline
\end{tabular}

Model summary: Adjusted $R^{2}=0.058 ; F=2.257 ; p=0.06$. 


\section{References}

Armitage, H. M. and Nicholson, R. (1993), Activity based Costing: a Survey of Canadian Practice, Issue Paper No. 3, Society of Management Accountants of Canada.

Ask, U. and Ax, C. (1992), 'Trends in the Development of Product Costing Practices and Techniques - A Survey of Swedish Manufacturing Industry, Paper presented at the 15th Annual Congress of the European Accounting Association, Madrid.

Bhimani, A., (1996), Management Accounting European Perspectives Oxford University Press, Oxford.

Bjornenak T. (1997a), Diffusion and accounting: the case of ABC in Norway, Management Accounting Research, Vol.8 No.1 pp 3-17

Bjornenak T. (1997b), Conventional wisdom and accounting practices, Management Accounting Research, Vol.8, No.4, pp 367-382.

Brierley, J. A., Cowton, C. J. and Drury, C. (2001), Research into Product Costing Practice: a European Perspective, The European Accounting Review, Vol. 10 No. 2, 215256.

Bright, J., Davies, R. E., Downes, C. A. and Sweeting, R.C. (1992), The deployment of Costing Techniques and Practices: A UK Study. Management Accounting Research, 3, 201-211.

Bromwich, M. (1990). The Case for Strategic Management Accounting: the Role of Accounting Information for Strategy in Competitive Markets. Accounting, Organizations and Society, 15, 1/2, 27-45.

Bruns, W. J., Jr., \& Waterhouse, J. H. (1975). Budgetary Control and Organization Structure. Journal of Accounting Research, Autumn, 177-203.

Chenhall, R. H. and Morris, D. (1986). The impact of structure, environment, and interdependence on the perceived usefulness of management accounting systems, The Accounting Review, 61, 16-35.

Chenhall, R. H. and Morris, D. (1993). The role of post completion audits, managerial learning, environmental uncertainty and performance, Behavioral Research in Accounting, 5, 170-186.

Chenhall, R.H. and Langfield-Smith, K. (1998), Adoption and benefits of management accounting practices: an Australian perspective, Management Accounting Research, 9, 120.

Coate, M. B., and McChesney, F. S. (1992). Empirical evidence on FTC enforcement of the merger guidelines, Economic Inquiry, 30, 277-293.

Cooper, R., 1990, Explicating the logic of ABC. Management Accounting, 68, 58-60. 
Dean, G. W., Joye, M. P. and Blayney, P. J. (1991), Strategic management accounting survey, Monograph No. 8, University of Sydney.

Drury, (2000), Management and Cost Accounting, London: Thomson Learning Business Press.

Drury, C., Braund, S., Osborne, P. and Tayles, M. (1993), A Survey of Management Accounting Practices in UK Manufacturing Companies, Chartered Association of Certified Accountants.

Drury C. and Tayles M. (2000), Cost System Design and Profitability Analysis in UK Companies, Chartered Institute of Management Accountants, London.

Emore J. R. and Ness J. A. (1991). 'The Slow Pace of Meaningful Changes in Cost Systems', Journal of Cost Management for the Manufacturing Industry, Winter, 36-45.

Farrell, J. and Shapiro, C. (1990). Horizontal mergers: an equilibrium analysis, American Economic Review, 80, 107-126.

Gordon, L.A. and Miller, D. (1976). A Contingency Framework for the Design of Accounting Information Systems, Accounting, Organizations and Society, 1, 59-69.

Govindarajan, V. (1984). Appropriateness of Accounting Data in Performance Evaluation: An Empirical Examination of Environmental Uncertainty as an Intervening Variable, Accounting, Organizations and Society, 9, 2, 125-136.

Govindarajan, V. and Anthony, R. N., (1983), How Firms Use Cost Data in Price Decisions, Management Accounting (USA), July, 30-36.

Green, F. B. and Amenkhienan, F. E. (1992), "Accounting Innovations : A Cross Sectional Survey of Manufacturing Firms". Journal of Cost Management for the Manufacturing Industry, Spring, 58-64.

Guilding, C. (1999) "Competitor-focussed accounting: an exploratory study", Accounting Organizations and Society, 24/7, 583-595.

Guilding, C. and McManus L. (2002). “The incidence, perceived merit and antecedents of customer accounting: an exploratory note”, Accounting, Organizations and Society, 27, 12, 45-59.

Gul, F. and Chia, Y. M. (1994). The effects of management accounting systems, perceived environmental uncertainty and decentralization on managerial performance: A test of three-way interaction, Accounting, Organizations and Society, 19, 413-426.

Horngren C., Foster G. and Datar S. (2000). Cost Accounting: A Managerial Emphasis, $10^{\text {th }}$ edition, New Jersey: Prentice Hall.

Innes, J. and Mitchell, F. (1991). "ABC: A survey of CIMA members", Management Accounting, October, 28-30.

Innes, J. \& Mitchell, F. (1995). "A survey of activity-based costing in the UK's largest 
companies", Management Accounting Research, June, 137-154.

Innes, J., Mitchell, F. and Sinclair, D.,(2000). "Activity-based Costing in the UK's Largest Companies: a Comparison of 1994 and 1999 Survey Results", Management Accounting Research, 11, 349-362.

Johnson H. T., and Kaplan, R., (1987). Relevance lost: the rise and fall of management accounting. Boston, MA, Harvard Business School Press.

Joshi, P.L. (1998), An explanatory study of activity-based costing practices and benefits in large size manufacturing companies in India, Accounting and Business Review, 5, 65-93.

Joye, M. P. and Blayney, P. J. (1990), Cost and management accounting practice in Australian manufacturing companies: survey results, Monograph No 7, University of Sydney.

Kaplan, R., (1984). Yesterday's accounting undermines production. Harvard Business Review, 62, 95-101.

Kaplan, R., (1990). Contribution margin analysis: no longer relevant Journal of Management Accounting Research, 2, 2-15.

Khandwalla, P. (1972) The Effects of Different Types of Competition on the Use of Management Control, Journal of Accounting Research, Autumn, 275-285.

Kohli, A. and Jaworski B. (1990), Market Orientation: The Construct, Research Propositions, and Managerial Implications, Journal of Marketing, 54, 1-18.

Lamminmaki D and Drury C, (2001), A comparison of New Zealand and British productcosting practices, The International Journal of Accounting, 36, 329-347.

Langfield-Smith K., Thorne H., and Hilton R. (1998). Management Accounting: An Australian Perspective, Second edition, London: McGraw-Hill.

Libby, T. and Waterhouse, J.H. (1996). Predicting Change in Management Accounting Systems, Journal of Management Accounting Research, 8, 137-150.

Lukka, K. and Granlund, M. (1996). Cost Accounting in Finland: Current Practice and Trends of Development, The European Accounting Review, 5:1, 1-28.

Merchant, K.A. (1981). The Design of the Corporate Budgeting System: Influences on Managerial Behavioural and Performance, The Accounting Review, 56, 4, 813-829.

Merchant, K.A. (1984). Influences on Departmental Budgeting: An Empirical Examination of a Contingency Model, Accounting, Organizations and Society, 9, 3/4, 291-310.

Mills, R. W. (1988) Pricing Decisions in UK Manufacturing And Service Companies. Management Accounting (UK), November, 38-39.

Simons, R., (1990). The Role of Management Control Systems in Creating Competitive 
Advantage: New Perspectives, Accounting, Organizations and Society, 15, 1/2, 127-143.

Tymon, W. G., Stout, D. E. and Shaw, K. N. (1998). Critical Analysis and Recommendations Regarding the Role of Perceived Environmental Uncertainty in Behavioral Accounting Research, Behavioral Research in Accounting, 10, $23-46$.

Werden, G. J. (1991). Horizontal mergers: comment, American Economic Review, 81, 1002-1006. 